\author{
М. Г. Малік \\ Дніпропетровський національний університет ім. Олеся Гончара
}

\title{
ВИКОРИСТАННЯ ГЛІАЛЬНОГО ФІБРИЛЯРНОГО КИСЛОГО БІЛКА МОЗКУ РИБ У ДІАГНОСТИЦІ СТАНУ ПРИРОДНОГО СЕРЕДОВИЩА
}

Розглянуто можливість використання в іхтіотоксикологічних дослідженнях молекулярного цитоскелетного маркера - гліального фібрилярного кислого білка (ГФКБ) мозку риб. Доведено, що тканиноспецифічні білки чутливі до впливу різноманітних несприятливих чинників на організм риб. Отримані дані дозволяють розглядати стан цитоскелета гліальних клітин як надійного та достовірного маркера.

\author{
М. Г. Малик
}

Днепропетровский национальный университет им. Олеся Гончара

\section{ИСПОЛЬЗОВАНИЕ ГЛИАЛЬНОГО ФИБРИЛЛЯРНОГО КИСЛОГО БЕЛКА МОЗГА РЫБ В ДИАГНОСТИКЕ СОСТОЯНИЯ ПРИРОДНОЙ СРЕДЫ}

Рассмотрена возможность использования в ихтиотоксикологических исследованиях молекулярного цитоскелетного маркера - глиального фибриллярного кислого белка (ГФКБ) мозга рыб. Доказано, что тканеспецифические белки являются чувствительными к воздействию разнообразных неблагоприятных факторов на организм рыб. Полученные данные дают возможность рассматривать состояние цитоскелета глиальных клеток как надежный и достоверный маркер.

\section{G. Malik}

Oles' Honchar Dnipropetrovsk National University

\section{USE OF GLIAL FIBRILLAR ACIDIC PROTEIN EXTRACTED FROM THE FISH BRAIN IN DIAGNOSTICS OF THE ENVIRONMENT STATE}

The possibility to use the molecular cytoskeletal marker - glial fibrillar acidic protein (GFAP) extracted from the fish brain - for conducting ichthyotoxicological research is analysed. It has been proved that histotypespecific proteins are positively sensitive to the influence of the various adverse factors upon a fish organism. The findings allow considering the glial cells' cytoskeleton state as reliable and authentic marker.

\section{Вступ}

Вплив різноманітних за походженням забруднювачів викликає багатофакторні зміни у біологічних системах. Іони деяких металів і промислові органічні розчинники розглядаються як найтоксичніші та небезпечні чинники ризику в регіонах зі значною концентрацією металургійних i хімічних підприємств [2; 3]. Навіть незначне підвищення концентрації цих забруднювачів у природних і штучних водоймах призводить до незворотних порушень у клітинах і тканинах живих організмів. 
Риби - зручні тест-об'єкти для біомоніторингу, але визначення вмісту важких металів, наявність патологічних уражень внутрішніх органів, порівняння змін морфофізіологічних індикаторів в організмі риб не дають чіткої а, головне, достовірної оцінки ушкоджувальних ефектів, завданих токсикантами.

При вивченні аспектів впливу на риб різних токсикантів широко використовують сучасні біохімічні методи [6]. Вони дають змогу спостерігати чіткі зміни обміну речовин, як правило, задовго до появи морфологічних, фізіологічних та інших відхилень від норми.

Останнім часом особливої актуальності в іхтіотоксикології набувають дослідження специфічних молекулярних маркерів, які адекватно відображають функціональний стан клітин і організму в цілому. Клітини нервової тканини (астроцити) надзвичайно чутливі до дії ушкоджувальних факторів, мають особливі фізіологічні та метаболічні можливості, життєво важливі для підтримання гомеостазу мозку. Пошкодження різного походження, хімічний та фізичний інсульт викликають характерну реактивну відповідь астроцитів - астрогліоз [7], який супроводжується підвищеним синтезом специфічного цитоскелетного компонента астроцитів - гліального фібрилярного кислого білка (ГФКБ). Білок проміжних філаментів гліальних клітин на сьогодні визнаний як надійний специфічний маркер астроцитів, зміни експресії якого відображають патогенетичні порушення ЦНС [12; 14].

Відомі зарубіжні наукові роботи стосовно дослідження реактивної відповіді астроцитів мозку риб, плазунів, птахів, ссавців [10; 12], але порівняльний аналіз стану гліального цитоскелета риб прісноводних екосистем - новий напрям екотоксикологічних досліджень в Україні, що зумовлює актуальність нашої роботи.

Основна мета роботи - апробація сучасного біохімічного методу визначення специфічних молекулярних маркерів для завдань іхтіотоксикології.

\section{Матеріал і методи досліджень}

Як тест-об’єкт обрано два види риб, масові та розповсюджені для прісноводних водойм України: плітка звичайна (Rutilus rutilus) і бичок-пісочник (Neogobius fluviatilis). Усього відібрано 30 екземплярів риб, які мешкали в різних за ступенем техногенного забруднення біотопах.

Іхтіологічний матеріал відбирали з весняних контрольно-біологічних сіткових уловів, а також аматорськими знаряддями лову (сіткопідйомником-«малявочницею» площею $1 \mathrm{~m}^{2}$ ) відповідно до загальновизнаних методик [4; 9]. Частину проб відбирали на забрудненій ділянці р. Самара (права притока р. Дніпро), куди надходять стоки хімічних, металургійних та інших виробництв. Як умовно чисту, контрольну ділянку вибрано акваторію нижньої ділянки р. Ворскла (Дніпродзержинське водосховище).

Кожний екземпляр плітки та бичка-пісочника піддавали зовнішньому повному морфоанатомічному аналізу, досліджували вигляд і стан внутрішніх органів риб (печінка, зябра, кишківник, гонади, нирки).

Дослідження вмісту та поліпептидного складу цитоскелетного білка астроглії (ГФКБ) проводили імунохімічним методом. Кількісний аналіз ГФКБ відбувався шляхом порівняння інтенсивності забарвлення відповідних поліпептидних зон між експериментальними та контрольними пробами, що віднесені до кількості загального білка у фракціях. Вміст загального білка визначали методом Лоурі в модифікації Г. Міллера [11]. Рівень продуктів перекисного окислення ліпідів (ПОЛ) визначали методом, який запропонував Ohkawa зі співавторами [13]. 
Отримані дані обробляли методами математичної статистики для малих вибірок [2]. Відносний вміст ГФКБ наводили у вигляді середньої величини, стандартної похибки середньої, достовірну різницю між групами оцінювали з використанням $t$-критерію Стьюдента $(p<0,05)$ після перевірки гіпотез про нормальність розподілу та відмінності між дисперсіями.

\section{Результати та їх обговорення}

Використання повного патолого-морфологічного дослідження риб не виявило серйозних ушкоджень, що можуть загрожувати життю особин (табл.). Лише у бичкапісочника Neogobius fluviailis із забрудненої ділянки р. Самара виявлено відхилення за показниками у деяких органах (печінка, гонади) порівняно з особинами з умовно чистого району р. Ворскла.

Табличя

Наявність патологічних змін внутрішніх органів (\%) у риб різних ділянок дослідження $(n=30)$

\begin{tabular}{|l|c|c|c|c|}
\hline \multirow{3}{*}{ Органи } & \multicolumn{2}{|c|}{$\begin{array}{c}\text { p. Самара Дніпровська } \\
\text { (забруднена зона) }\end{array}$} & \multicolumn{2}{c|}{$\begin{array}{c}\text { р. Ворскла } \\
\text { (умовно чиста зона) }\end{array}$} \\
\cline { 2 - 5 } & $\begin{array}{c}\text { Rutilus rutilus } \\
\text { (Linnaeus, 1758) }\end{array}$ & $\begin{array}{c}\text { Neogobius fluviatilis } \\
\text { (Pallas, 1814) }\end{array}$ & $\begin{array}{c}\text { Rutilus rutilus } \\
\text { (Linnaeus, } 1758)\end{array}$ & $\begin{array}{c}\text { Neogobius fluviatilis } \\
\text { (Pallas, 1814) }\end{array}$ \\
\hline Печінка & $0,18 \pm 0,02$ & $2,21 \pm 0,04^{*}$ & $1,21 \pm 0,03$ & $2,13 \pm 0,04$ \\
\hline Селезінка & $1,11 \pm 0,03^{*}$ & $1,13 \pm 0,03^{*}$ & $1,24 \pm 0,03$ & $1,13 \pm 0,03$ \\
\hline Серце & $0,12 \pm 0,02^{*}$ & $0,12 \pm 0,02$ & $0,17 \pm 0,02$ & $0,16 \pm 0,02$ \\
\hline Нирки & $1,24 \pm 0,03^{*}$ & $1,11 \pm 0,02^{*}$ & $1,15 \pm 0,02$ & $1,14 \pm 0,01$ \\
\hline Гонади & $1,19 \pm 0,03^{*}$ & $1,35 \pm 0,04$ & $1,13 \pm 0,04$ & $1,13 \pm 0,04$ \\
\hline
\end{tabular}

Примітка: ${ }^{*}-p<0,05$.

Отримані дані не дають змоги стверджувати, що об’єкти, у яких не виявлено ознак патологічних порушень, $є$ цілком здоровими і не підлягали дії стресових факторів. Щоб отримати повну інформацію про їх стан, необхідно проводити ретельніше дослідження молекулярних процесів, які адекватно та достовірно відображають стан клітин усього організму.

Результати визначення вмісту загального білка у різних тканинах риб (печінка, м'язи, мозок) не виявили достовірної різниці між групою риб з умовно чистої акваторії р. Ворскла та із забрудненої ділянки р. Самара.

Дослідження специфічних молекулярних маркерів мозку риб із різних біотопів виявило, що відносний вміст цитоскелетного маркера для нервової системи (ГФКБ) мозку $R$. rutilus та $N$. fluviailis із забрудненої ділянки р. Самара достовірно підвищувався (3 48 до $83 \%$ ) порівняно 3 групами риб умовно чистої акваторії p. Ворскла. Підвищена експресія ГФКБ свідчить про розвиток астрогліозу у відповідь на вплив різних чинників, у першу чергу - різноманітних токсикантів (у тому числі фенолів, пестицидів, важких металів, уміст яких у р. Самара набагато більший порівняно з умовно чистою ділянкою р. Ворскла) [1].

Підвищення вмісту білка проміжних філаментів мозку плітки та бичка-пісочника свідчить про активацію фібрилогенезу, який $є$ основним показником реактивної відповіді астроцитів на пошкодження різної природи, або адекватною реакцією мозку, яка спрямована на захист та підтримання нейронів і функціональної стабільності всього організму. Підвищення вмісту ГФКБ (рис. 1) супроводжувалось не лише зростанням вмісту інтактного поліпептиду 49 кДа, а також появою фрагментів ГФКБ меншою молекулярною масою. 


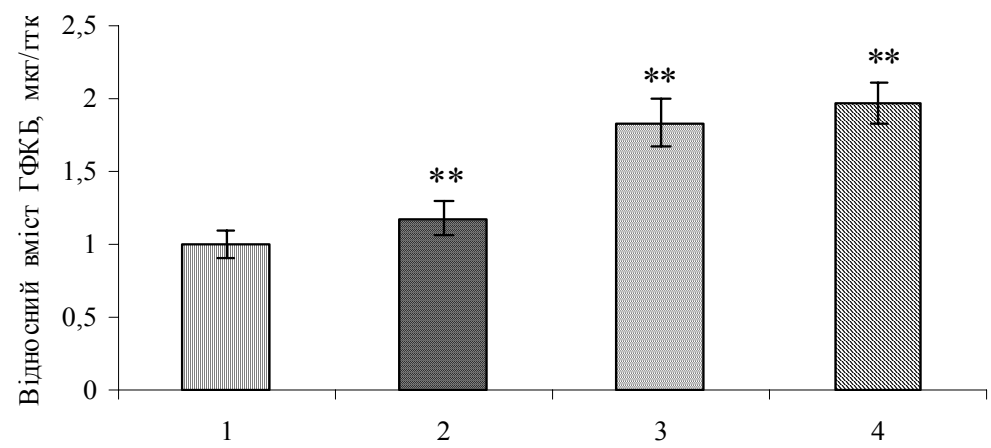

Рис. 1. Відносний вміст ГФКБ у мозку риб:

$1-R$. rutilus із чистого району р. Ворскла, $2-N$. fluviatilis із забрудненого району р. Самара, $3-R$. rutilus iз забрудненого району р. Самара, $4-N$. fluviatilis із забрудненого району р. Самара; ** - достовірні зміни відносно контрольної групи $(p<0,01)$

Надмірне підвищення вмісту цих деградованих поліпептидів ГФКБ виявлено у придонного виду $N$. fluviatilis, на нашу думку, є доказом накопичення у донних відкладах ріки Самара токсичних водонерозчинних полютантів та їх впливу на живі організми (рис. 2).

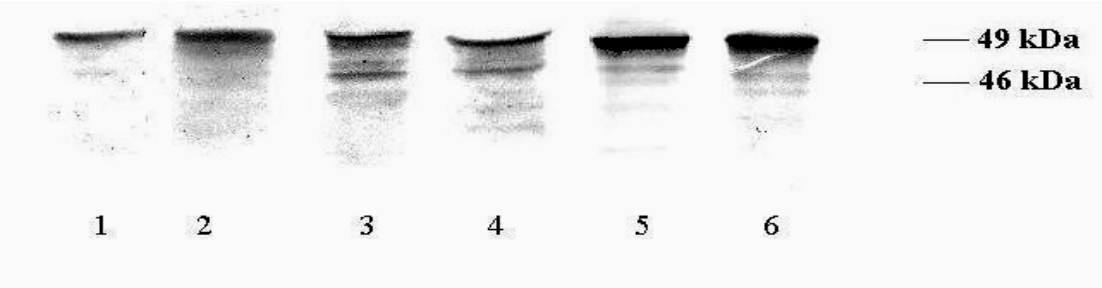

Рис. 2. Результати імуноблотингу водорозчинних фракцій білків із мозку риб:

1-2 - R. rutilus із забрудненої ділянки ріки Самара, 3 - R. rutilus із забрудненої центральної частини

p. Самара, $4-R$. rutilus із забрудненої нижньої частини р. Самара, $5-N$. fluvitilis із забрудненої

центральної частини р. Самара, 6 - N. fluvitilis із забрудненої нижньої частини р. Самара

Зміна швидкості перекисного окиснення ліпідів (ПОЛ) та накопичення тіобарбітурових (ТБК) реактивів під дією токсикантів виявила такі закономірності: у м'язах швидкість ферментативного окиснення ліпідів збільшується у 1,3-1,5 раза, у печінці - в 1,2-1,4 раза порівняно 3 контрольною групою. Показники оксидативного стресу та цитоскелетні зміни мали високий коефіцієнт кореляції $(r=0,79)$ між групами iз p. Самара і р. Ворскла.

Це вказує на високий метаболічний статус білків мозку риб, який є засобом забезпечення життєздатності риб у стресових умовах. Головний мозок має провідну роль у визначенні характерних реакцій риб на дію різних токсинів [8]. Мозок бере участь у формуванні рефлекторних реакцій риб на дію токсинів. Збудження, яке виникає за допомогою таких реакцій, швидко поширюється по всьому організму, що призводить до втрати або погіршення рефлексів рівноваги, зниження тонусу м'язів, погіршення локомоторики тощо.

Достовірне підвищення експресії білка гліальних проміжних філаментів свідчить про індукований астрогліоз, тобто функціональну відповідь нейроглії на несприятливий вплив. Характерне збільшення деградованих поліпептидних фрагментів ГФКБ ознака цитоскелетних перебудов, порушення стану цитоскелета, морфології та функціонування клітин нервової тканини. 
Оксидативний стрес розглядають як одне з найпоширеніших метаболічних порушень організму, індукованих дією несприятливих факторів. Проміжні високореактивні продукти, що утворюються у процесі розвитку оксидативного стресу, - важливий показник нейродегенерації та зниження життєздатності в умовах дії токсичних забруднювачів різної природи. Порушення на молекулярному рівні лежить в основі патологічних процесів і відбивається на наступних, вищих рівнях біологічної організації, у тому числі на структурно-функціональній організації екосистем. Реактивний астрогліоз мозку риб, що мешкають на забрудненій акваторії р. Самара, вказує на певний рівень адаптації клітин нервової системи до несприятливих умов, викликаних забрудненням.

\section{Висновки}

Вивчення впливу забруднювальних речовин на гідроекосистему не може бути виконане проведенням дослідів лише на організмовому рівні, оскільки дозволяє виявити аномальні зміни лише на пізніх стадіях інтоксикації, коли організм перебуватиме на межі загибелі. Для того, щоб не допустити такої помилки, необхідно застосовувати біохімічні методи діагностики, оскільки підтримання необхідного рівня метаболічних процесів у тканинах нервової системи водних тварин при інтоксикації здійснюється головним чином за рахунок мобілізації можливих адаптаційних процесів, основу яких становлять фізіолого-біохімічні механізми. Дослідження реактивної відповіді астроцитів мозку різних тварин - апробована та результативна методика в екотоксикології, що підтверджується і нашими даними.

Цитоскелетні перебудови мозку риб виникли під впливом несприятливих антропогенних чинників навколишнього середовища. Це дає змогу розглядати ГФКБ як достовірний маркер токсичного впливу полютантів, за допомогою якого можна оцінити ушкоджувальні ефекти на ранніх етапах і розробити ефективні заходи компенсації патогенетичних порушень.

\section{Бібліографічні посилання}

1. Звіт про стан навколишнього природного середовища в Дніпропетровській області за 2005 рік. - Д. : УПРЕ, 2006. - 173 с.

2. Кокунин В. А. Статистическая обработка данных при малом числе опытов // Укр. биохим. журнал. - 1975. - Т. 7, № 6. - С. 776-791.

3. Кораблева А. И. Оценка уровня органического загрязнения Запорожского водохранилища и предложения по разработке природоохранных мероприятий. - Д. : Дніпро, 1992. - 52 с.

4. Методика збору і обробки іхтіологічних та гідробіологічних матеріалів. - К. : Інститут рибного господарства, 1998. - 67 с.

5. Методи гідроекологічних досліджень поверхневих вод // О. М. Арсан, О. А. Давидов, Т. М. Дьяченко та ін. / За ред. В. Д. Романенка. - К. : Логос, 2006. - 408 с.

6. Недзвецкий В. С. Возможности использования молекулярних компонентов с целью сохранения биологического разнообразия в условиях действия неблагоприятных факторов / В. С. Недзвецкий, А. А. Тихомиров, С. В. Кириченко и др. // Екологія та ноосферологія. - 2005. - Т. 16, № 3-4. - С. 215-221.

7. Недзвецкий В. С. Характеристика белков промежуточных филаментов нервной ткани в норме и при различных видах патологии // Автореф. дисс. ... канд. биол. наук. - Д. : ДГУ, 1990. - 16 с.

8. Новіцький Р. О. Дослідження гістоспецифічних маркерів для біоіндикації у водних екосистемах / Р. О. Новіцький, М. Г. Малік, В. С. Недзвецький // Сучасні проблеми водних екосистем. Тези доп. Міжнар. конф. - Д. : ДНУ, 2007. - С. 37-38.

9. Правдин И. Ф. Руководство по изучению рыб (преимущественно пресноводных). - М. : Пищ. пром-сть, 1966. -376 с.

96 
10. Kalman M. Glial fibrillary acidic protein-immunopositive structures in the brain of a crocodilian, Caiman crocodilus, and its bearing on the evolution of astroglia / M. Kalman, M. Pritz // The J. of Comparative Neurology. - 2001. - P. 460-480.

11. Miller G. L. Protein determination for large numbers of samples // Anal. Chem. - 1959. - Vol. 31, N 5. - P. 964-966.

12. Quantitative aspects of reactive gliosis: A review / W. T. Norton, D. A. Aquino, I. Hozumi et al. // Neurochem. Res. - 1992. - Vol. 17, N 9. - P. 877-885.

13. Ohkawa H. Assay for lipid peroxides in animal tissues by thiobarbituric acid reaction / H. Ohkawa, N. Ohishi, K. Yagi // Anal. Biochem. - 1979. - Vol. 95, N 2. - P. 351-358.

14. Reactive astrocytes: Cellular and molecular cues to biological function / J. L. Ridet, S. K. Malhotra, A. A. Privat et al. // Trends Neurosci. - 1997. - Vol. 20, N 12. - P. 570-577.

Надійшла до редколегії 10.06.2010 